\title{
LETTER
}

\section{Quality of life in patients aged 80 or over after intensive care unit discharge}

\author{
Jacqueline Koeze and Jan G Zijlstra* \\ See related research by Tabah et al., http://ccforum.com/content/14/1/R2
}

In a recent issue of Critical Care, Tabah and colleagues [1] describe the quality of life after intensive care unit (ICU) discharge in octogenarians. The quality is not significantly decreased by ICU admission. This is good news and it is reassuring. There are old patients profiting from ICU admission without loss of quality of life. However, we have some concerns. Only 18 of 106 evaluated patients agreed to another ICU admission. Five did not agree, seven for various reasons refused evaluation, three had dementia, and 73 did not reach 1-year survival. So only the happy few were evaluated. What worries us are the feelings of the 86 patients and families that could not or did not agree to readmission. There is not much doubt that ICU admission causes suffering to patients and families. How can the suffering of 86 patients and families be balanced against the positive feelings of 18 patients? This is an ethical or philosophical dilemma that is not easy to solve and that is subject to large cultural differences. In a previous paper, the authors report that many octogenarians are already refused admission to the ICU [2]. We have to improve this triage model, not primarily to refuse more but to select better. A 1-year mortality rate of $70 \%$ is unacceptably high. Improvement should not be expected from better care but from better selection. Avoidance of unnecessary suffering and providing a good death can also mean tremendous improvement in the care of critically ill octogenarians. And it provides time and resources for improvement of care of those who will benefit.

\section{Author's response}

Alexis Tabah

Koeze and Zijlstra question the usefulness of admitting octogenarians to the ICU because of the high mortality of these patients. As our selection criteria and triage models improve, we are dealing with a greater number of elderly patients in good physical health. Higher mortality is explained mostly by a lower life expectancy at higher ages.

We select our elderly patients based on their functional status and previous medical history [2]. We believe there is room for improvement in the selection process by trying to understand the opinion and desires of the patient. This is the subject of ongoing research in our team.

We agree that the balance between the suffering and the positive feelings of patients and their relatives will always remain difficult to determine. However, we believe

*Correspondence: j.g.zijlstra@icv.umcg.nl

Department of Critical Care, University Medical Center Groningen, Hanzeplein 1, 9713 GZ Groningen, The Netherlands that we can improve care in the ICU as well as in the wards to which the patients are subsequently discharged. Indeed, referring elderly patients to a specialized geriatric unit would probably increase their chances of recovery [3].

The existence of promising interventions throughout the hospital stay [4] in order to decrease post-traumatic stress disorder and improve quality of life may diminish the suffering that intensive care causes patients and families. The best we can do is try to improve our triage tools to reduce the number of unnecessary admissions and refine our skills to preserve the patients' humanity and bonds with their family while they are within our walls $[5,6]$.

Abbreviation

ICU, intensive care unit

Competing interests

The authors declare that they have no competing interests.

Published: 30 July 2010 


\section{References}

1. Tabah A, Philippart F, Timsit JF, Willems V, Français A, Leplège A, Carlet J, Brue C, Misset B, Garrouste-Orgeas M: Quality of life in patients aged 80 or over after ICU discharge. Crit Care 2010, 14:R2.

2. Garrouste-Orgeas M, Timsit JF, Montuclard L, Colvez A, Gattolliat O, Philippart F, Rigal G, Misset B, Carlet J: Decision-making process, outcome, and 1-year quality of life of octogenarians referred for intensive care unit admission. Intensive Care Med 2006, 32:1045-1051.

3. Somme D, Andrieux N, Guérot E, Lahjibi-Paulet H, Lazarovici C, Gisselbrecht M, Fagon JY, Saint-Jean O: Loss of autonomy among elderly patients after a stay in a medical intensive care unit (ICU): a randomized study of the benefit of transfer to a geriatric ward. Arch Gerontol Geriatr 2010, 50:e36-40.

4. Jones C, Skirrow P, Griffiths RD, Humphris GH, Ingleby S, Eddleston J, Waldmann C, Gager M: Rehabilitation after critical illness: a randomized, controlled trial. Crit Care Med 2003, 31:2456-2461.

5. Garrouste-Orgeas M, Philippart F, Timsit JF, Diaw F, Willems V, Tabah A, Bretteville G, Verdavainne A, Misset B, Carlet J: Perceptions of a 24-hour visiting policy in the intensive care unit. Crit Care Med 2008, 36:30-35.

6. Garrouste-Orgeas M, Willems V, Timsit JF, Diaw F, Brochon S, Vesin A, Philippart F, Tabah A, Coquet I, Bruel C, Moulard ML, Carlet J, Misset B: Opinions of families, staff, and patients about family participation in care in intensive care units. J Crit Care 2010 Apr 30. [Epub ahead of print].

doi:10.1186/cc9088

Cite this article as: Koeze J, Zijlstra JG: Quality of life in patients aged 80 or over after intensive care unit discharge. Critical Care 2010, 14:434. 